\title{
Nitrogen competition between three dominant plant species and microbes in a temperate grassland
}

\author{
Shengnan Ouyang • Yuqiang Tian • Qianyuan Liu • \\ Li Zhang • Ruixue Wang $\cdot$ Xingliang Xu
}

Received: 28 September 2015 / Accepted: 21 April 2016/Published online: 8 May 2016

(C) Springer International Publishing Switzerland 2016

\begin{abstract}
Background and aims To test the hypothesis that dominant plant species could acquire different nitrogen $(\mathrm{N})$ forms over a spatial scale and they also have the ability to compete for available $\mathrm{N}$ with microbes.

Methods A short-term ${ }^{15} \mathrm{~N}$ labeling experiment was conducted in the temperate grassland ecosystem of North China in July of 2013. Three $\mathrm{N}$ forms $\left(\mathrm{NO}_{3}{ }^{-}, \mathrm{NH}_{4}{ }^{+}\right.$and glycine) labeled with ${ }^{15} \mathrm{~N}$ were injected into the two soil depths $(0-5$ and $5-15 \mathrm{~cm})$ surrounding each plant to explore $\mathrm{N}$ acquisition by plants and microbes. Three dominant plant species (Artemisia frigida, Cleistogenes squarrosa and Artemisia capillaris) were investigated.

Results Two hours after ${ }^{15} \mathrm{~N}$ labeling, all three dominant plant species absorbed both organic and inorganic $\mathrm{N}$, but different patterns were observed at two soil depths. Uptake of $\mathrm{NO}_{3}{ }^{-}$was significantly higher at $0-5 \mathrm{~cm}$ than at $5-15 \mathrm{~cm}$ soil depth among all the dominant plant
\end{abstract}

Responsible Editor: Ad C. Borstlap.

S. Ouyang $\cdot$ Y. Tian $(\bowtie) \cdot$ R. Wang

Center for Human-Environment System Sustainability (CHESS), State Key Laboratory of Earth Surface Processes and Resource Ecology, Beijing Normal University, Haidian District,

Beijing 100875, China

e-mail: tyq@bnu.edu.cn

Q. Liu $\cdot$ L. Zhang $\cdot$ X. Xu

Key Laboratory of Ecosystem Network Observation and Modeling, Institute of Geographic Sciences and Natural Resources Research, Chinese Academy of Sciences, Beijing 100101, China

$\mathrm{X} . \mathrm{Xu}$

e-mail: xuxingl@hotmail.com species. ${ }^{15} \mathrm{~N}$ recovery by microbes was significantly higher than plants. However, ${ }^{15} \mathrm{~N}$ recovery by plants showed different patterns over soil depths.

Conclusions Dominant plant species in the temperate grassland have different patterns in acquisition of $\mathrm{N}$ added to soil in organic form and absorption of inorganic $\mathrm{N}$, and microbes were more effectively than plants at competing for $\mathrm{N}$ in a short-term period.

Keywords Inorganic $\mathrm{N} \cdot$ Microbes $\cdot{ }^{15} \mathrm{~N} \cdot \operatorname{Root} \mathrm{N}$ uptake $\cdot$ Temperate grassland

\section{Introduction}

In terrestrial ecosystems, all living organisms rely on the same nutrients, which form the basis for interspecific competition between plants and microbes (Kuzyakov and $\mathrm{Xu} 2013$ ). Nitrogen (N) is one of the most essential elements limiting plant net primary production (NPP) in most terrestrial ecosystems (Vitousek and Howarth 1991; Lebauer and Treseder 2008), and the strong competition for $\mathrm{N}$ often occurs between plants and microbes. Clarifying plant-microbial competition for $\mathrm{N}$ will improve our understanding how N controls NPP and plant species coexistence.

In soil, there are diverse chemical forms of $\mathrm{N}$ that can be used by plants and microbes (Harrison et al. 2008; Kaštovská and Šantrůčková 2011), such as $\mathrm{NH}_{4}{ }^{+}, \mathrm{NO}_{3}{ }^{-}$and organic $\mathrm{N}$, including free amino acids and small molecular peptides and proteins (PaungfooLonhienne et al. 2008, 2012; Hill et al. 2011a, 2011b, 
2012; Wilkinson et al. 2014, 2015). Some of studies showed that in short-term experiments, microbes took up more ${ }^{15} \mathrm{NH}_{4}{ }^{+}$and ${ }^{15} \mathrm{NO}_{3}{ }^{-}$than plants in some of ecosystems such as in the arctic tundra (Marion et al. 1982; Schimel and Chapin 1996) and annual grasslands (Jackson et al. 1989), and some of studies proved that plants took up more inorganic $\mathrm{N}$ than soil microbes (Kaye and Hart 1997; Jaeger et al. 1999; Schimel and Bennett 2004; Bardgett et al. 2003; Harrison et al. 2007, 2008). In the past three decades, organic $\mathrm{N}$ in the form of amino acids were found that could be directly acquired by plants from the soil, which is a significant portion of the total soluble $\mathrm{N}$ pool and an important $\mathrm{N}$ source for plants of alpine and subalpine grasslands (Raab et al. 1996, 1999; Owen and Jones 2001; Xu et al. 2006, 2011a; Gao et al. 2014). A large number of studies conducted in the field or laboratory have emphasized on the utilization of available $\mathrm{N}$ by plants and microbes (Schimel and Chapin 1996; Bardgett et al. 2002, 2003; Kuzyakov and $\mathrm{Xu}$ 2013). Microbes utilize available $\mathrm{N}$ more effectively than plants over a short time, although in the long run, plants might be more competitive (Harrison et al. 2007; Kuzyakov and Xu 2013). A temporal niche for $\mathrm{N}$ acquisition often occurs between plants and microbes (Jaeger et al. 1999). Initially after $\mathrm{N}$ additions, microbes often acquire much more $\mathrm{N}$ than plants because soil microbes have a large surface-volume ratio (Kaye and Hart 1997; Wilkinson et al. 2014). With timing, added N gradually enters plants because they show long life (Kuzyakov and $\mathrm{Xu}$ 2013). The patterns of $\mathrm{N}$ uptake by plants and microbes may be the most important mechanism of avoiding competition for plant species coexistence and plant diversity maintenance (McKane et al. 2002; Miller and Bowman 2003; Wang et al. 2012). The differentiation of chemical niches for $\mathrm{N}$ acquisition among dominant plant species might be the result of long-term evolution and adaptation (Lambers et al. 2009), which varies over spatial and temporal scales in many ecosystems. It is well documented that soil $\mathrm{N}$ availability varies vertically with soil depth (Zhu and Carreiro 2004; Xu et al. 2011b).

In regards to the plant-microbial competition for $\mathrm{N}$, a large number of studies have focused on $\mathrm{N}$ uptake strategies by plants and microbes in various ecosystems, such as alpine meadows and tundra, subtropical and forest agricultural ecosystems (McKane et al. 2002;
Buckeridge and Jefferies 2007), but fewer investigations have been conducted on the plant species level. The mechanism, utilization and preference of organic and inorganic $\mathrm{N}$ by plant species is still unclear, although more work related to the nutrient cycling has been conducted (Wu et al. 2011; Zhang et al. 2013; Kleinebecker et al. 2014). How these temperate grassland plant species acquire $\mathrm{N}$ from the soil and what the patterns of $\mathrm{N}$ uptake between plants and microbes remain unclear. We designed this experiment to explore these issues.

Artemisia frigida is a plant species involved in the degradation of grasslands. Due to long-term overgrazing and unplanned grassland utilization, A. frigida accompanied with $C$. squarrosa and A. capillaris can become the dominant species in the temperate steppe ecosystem of the farming pastoral ecotone of northern China. To investigate how these dominant plants and microbes absorb organic and inorganic $\mathrm{N}$ in the temperate grassland, we conducted a ${ }^{15} \mathrm{~N}$ short-term labeling experiment to test the hypotheses: (1) plants and microbes have different $\mathrm{N}$ acquisition strategies to acquire different chemical $\mathrm{N}$ forms; and (2) microbes compete for $\mathrm{N}$ more efficiently than plants over a short time. From the nutrient cycle standpoint, this study provides useful scientific data and theories on how to reduce degradation and promote restoration of grasslands and further improves our management capacity of degraded grasslands in the farming pastoral ecotone of northern China.

\section{Materials and methods}

Study site and target species

The experiment was conducted in a temperate grassland ecosystem in Inner Mongolia of North China (41 $35^{\prime}$ $50^{\prime \prime} \mathrm{N}, 114^{\circ} 51^{\prime} 45^{\prime \prime} \mathrm{E}, 1500 \mathrm{~m}$ above sea level). The area is located in the southern margin of the farming-pastoral ecotone of North China and is characterized by a semi-arid continental climate. During the past 35 years, the mean annual temperature and annual precipitation were $2.1{ }^{\circ} \mathrm{C}$ and $384.4 \mathrm{~mm}$, respectively. The steppe areas are dominated by Artemisia frigida, Cleistogenes squarrosa, Artemisia capillaris, Stipa krylovii and Leymus chinensis (Xu et al. 2014). We chose the important values of three of the largest plant species, i.e., A. frigida, C. squarrosa and A. capillaris, 
as our target plant species. The zonal soils were chestnut soil (Chinese Soil Taxonomy Research Group 2001) and corresponded to Calcic Orthic Aridisol according to the USDA Soil Taxonomy (Soil Survey Staff 1987), which are poor in organic matter $(2.7 \%)$ and total $\mathrm{N}$ $(0.14 \%)$ (Table 1$)$.

\section{Experiment design}

A $100 \mathrm{~m} \times 100 \mathrm{~m}$ area, uniform in cover and species condition ( $\mathrm{Xu}$ et al. 2014), was selected in a fenced temperate steppe in July, 2013. A total of 84 circular microplots (10 cm in diameter) within the experimental site were randomly established including 72 labeled microplots $\left({ }^{15} \mathrm{~N}\right.$-labeled) and 12 control microplots $\left({ }^{15} \mathrm{~N}\right.$-unlabeled). They were equally divided into three groups: A. frigida, C. squarrosa and A. capillaris. Each group included two soil depth treatments $(0-5 \mathrm{~cm}$ and 5-15 cm) was labeled with ${ }^{15} \mathrm{NH}_{4}{ }^{+}\left(\left({ }^{15} \mathrm{NH}_{4}\right)_{2} \mathrm{SO}_{4}, 98.4\right.$ atom\% $\left.{ }^{15} \mathrm{~N}\right),{ }^{15} \mathrm{NO}_{3}{ }^{-}\left(\mathrm{K}^{15} \mathrm{NO}_{3}, 98.2\right.$ atom\% $\left.{ }^{15} \mathrm{~N}\right)$ or glycine- ${ }^{15} \mathrm{~N}\left(\mathrm{C}_{2} \mathrm{H}_{5}{ }^{15} \mathrm{NO}_{2}, 95\right.$ atom $\left.\%{ }^{15} \mathrm{~N}\right) .{ }^{15} \mathrm{~N}$ tracers were dissolved in distilled water and injected into the soil at $2.5 \mathrm{~cm}$ depth for $0-5 \mathrm{~cm}$ soil depth treatment and $10 \mathrm{~cm}$ for the $5-15 \mathrm{~cm}$ treatment with four replicates per treatment. A total of $24.3 \mathrm{mg} \mathrm{N}$ of solid $\mathrm{N}$ mixed material $\left(\left(\mathrm{NH}_{4}\right)_{2} \mathrm{SO}_{4}, \mathrm{KNO}_{3}\right.$ and glycine, only one $\mathrm{N}$ form labeled by ${ }^{15} \mathrm{~N}$ ) was dissolved in $200 \mathrm{ml}$ of distilled water with equivalent $\mathrm{N}$ amount $(8.1 \mathrm{mg})$ of $\mathrm{NH}_{4}{ }^{+}-\mathrm{N}, \mathrm{NO}_{3}{ }^{-}-\mathrm{N}$ and glycine-N. The total amount of $\mathrm{N}$ added to soils was equal to $0.060 \mathrm{~g} \mathrm{~N} \mathrm{~m}^{-2}$. To ensure ${ }^{15} \mathrm{~N}$ evenly distributed, total $4 \mathrm{ml}$ of labeled solutions were injected in each soil depth of each microplot, around the plant in a triangle (i.e., the plant generally growing in the center of a triangle). When the plant was located at the center of the triangle, we injected the solution at a distance of about $0.5 \mathrm{~cm}$ far from the center to avoid injecting in roots. Each $1 \mathrm{ml}$ of ${ }^{15} \mathrm{~N}$ solution

Table 1 Characteristics of the upper $15 \mathrm{~cm}$ soil in the temperate grassland of North China (means \pm SE; $n=16$ )

\begin{tabular}{lc}
\hline Soil organic matter $\left(\mathrm{mg} \mathrm{g}^{-1}\right)$ & $27 \pm 2$ \\
Total nitrogen $\left(\mathrm{mg} \mathrm{g}^{-1}\right)$ & $1.4 \pm 0.09$ \\
$\mathrm{C} / \mathrm{N}$ & $11.3 \pm 0.05$ \\
$\mathrm{pH}$ & $8.17 \pm 0.03$ \\
$\mathrm{NH}_{4}{ }^{+}-\mathrm{N}\left(\mu \mathrm{g} \mathrm{N} \mathrm{g}^{-1}\right.$ d.w.soil $)$ & $3.05 \pm 0.09$ \\
$\mathrm{NO}_{3}{ }^{-}-\mathrm{N}\left(\mu \mathrm{g} \mathrm{N} \mathrm{g}^{-1}\right.$ d.w.soil $)$ & $7.12 \pm 0.09$ \\
glycine-N $\left(\mu \mathrm{g} \mathrm{N} \mathrm{g}^{-1}\right.$ d.w.soil $)$ & $1.39 \pm 0.09$ \\
\hline
\end{tabular}

was injected on all the three vertexes and in the center of the triangle. The experiment was conducted at 10:00 am on a sunny day in July 2013.

\section{Sampling and analysis}

Because of the rapid turnover of amino acids in the soil (Jones and Kielland 2002), plant and soil samples were immediately harvested $2 \mathrm{~h}$ after the ${ }^{15} \mathrm{~N}$ labeling. Soil cores (10 $\mathrm{cm}$ in diameter) were dug up to $15 \mathrm{~cm}$ depth for all labeled or unlabeled microplots with a soil probe. All plant materials were carefully picked up from soil cores and classified into aboveground and belowground parts. Roots were rinsed with tap water and soaped in $0.5 \mathrm{mM} \mathrm{CaCl}_{2}$ solution for $30 \mathrm{~min}$ and again rinsed with distilled water to remove ${ }^{15} \mathrm{~N}$ absorbed on the root surface (Xu et al. 2011a). Both aboveground plants and roots were dried at $70{ }^{\circ} \mathrm{C}$ for $48 \mathrm{~h}$. Dried samples were weighed and ground into fine powder using a ball mill (MM2, Fa Retsch). All soil from the core was put into a plastic bag and immediately taken into the laboratory within 1 hour.

The fresh soil was processed through $2 \mathrm{~mm}$ mesh sieve to remove coarse fragments for measuring $\mathrm{pH}$, moisture content, microbial biomass $\mathrm{N}$, inorganic $\mathrm{N}$ $\left(\mathrm{NH}_{4}{ }^{+}\right.$and $\left.\mathrm{NO}_{3}{ }^{-}\right)$, glycine, microbial ${ }^{15} \mathrm{~N}$, total $\mathrm{N}$ and soil organic carbon (SOC). The soil $\mathrm{pH}$ was measured using a glass electrode method with a 1:2.5 soil-to-water ratio. The soil moisture content dried at $105{ }^{\circ} \mathrm{C}$ was measured by oven drying method. Total $\mathrm{N}$ was measured by Kjeldahl digestion with a salicylic acidification (Pruden et al. 1985). SOC was measured with wet oxidation by acid dichromate solution described by Kalembasa and Jenkinson (1973). The microbial biomass $\mathrm{N}$ was analyzed by a chloroform fumigation-direct extraction technique (Brookes et al. 1985). Two set of subsamples of $40 \mathrm{~g}$ of fresh soil from cooled soil samples were placed in beakers. One set of subsample was placed in a desiccator and fumigated with alcohol-free $\mathrm{CHCl}_{3}$ for $24 \mathrm{~h}$. After fumigation, the subsamples were immediately extracted with $0.05 \mathrm{~mol}$ $\mathrm{L}^{-1} \mathrm{~K}_{2} \mathrm{SO}_{4}$ (4:1 ratio of solution to dry soil weight) (Werth and Kuzyakov 2010). The extracts were shaken for $1 \mathrm{~h}$ with $150 \mathrm{r} \mathrm{min}^{-1}$ of shaker and then filtered through Whatman No. 1 paper. And meanwhile, another set of subsamples was also extracted with $0.05 \mathrm{~mol} \mathrm{~L}^{-1}$ $\mathrm{K}_{2} \mathrm{SO}_{4}$ (Werth and Kuzyakov 2010). All of the filtered extracts were analyzed for $\mathrm{NH}_{4}{ }^{+}$and $\mathrm{NO}_{3}{ }^{-}$using an auto-analyzer (AA3, Bran-Luebbe, Germany). The soil 
glycine concentration was measured in the extracts (Näsholm et al. 1987) by high performance liquid chromatography (Waters 515, Waters Inc., USA).

Aliquots ( $2 \mathrm{mg}$ ) of plant materials were weighed into tin capsules to analyze ${ }^{15} \mathrm{~N}$ atom\% by continuous-flow gas isotope ratio mass spectrometry (MAT253, Finnigan MAT, Bremen, Germany), coupled to a ConFlo III device (Finnigan MAT, Bremen, Germany) and to an elemental analyzer (EA 1112, CE Instruments, Milan, Italy). ${ }^{15} \mathrm{~N}$ incorporation into the microbial biomass was determined by chloroform fumigation (Brookes et al. 1985).

\section{Calculation and statistics}

Atom $\%{ }^{15} \mathrm{~N}$ excess (APE) was calculated as the atom $\%{ }^{15} \mathrm{~N}$ difference between labeled and control plant by the following equation (Hertenberger and Wanek 2004):

$$
\mathrm{APE}=\text { atom } \% \text { plant-labeled }- \text { atom } \% \text { plant-control }
$$

where atom $\%_{\text {plant-labeled }}$ refers to the atom $\%{ }^{15} \mathrm{~N}$ from the ${ }^{15} \mathrm{~N}$-labeled plant, atom $\%$ plant-control refers to the atom $\%{ }^{15} \mathrm{~N}$ from the same control plant.

${ }^{15} \mathrm{~N}$ Uptake by individual plant species was calculated by multiplying $\mathrm{N}$ content $\left(\mu \mathrm{g} \mathrm{N} \mathrm{g} \mathrm{g}^{-1}\right.$ d.w. root), APE and biomass $\left(\mathrm{g} \mathrm{m}^{-2}\right.$ ) (McKane et al. 2002) as following:

$\mathrm{U}_{\text {labeled }}=\mathrm{N}_{\text {content }} \times$ APE $\times$ Biomass

Uptake of available $\mathrm{N}$ form by individual plant species ( $\mu \mathrm{g} \mathrm{N} \mathrm{g}{ }^{-1}$ d.w. root) corresponding to the ${ }^{15} \mathrm{~N}$-labeled $\mathrm{N}$ form was calculated by the following equation (McKane et al. 2002):

$\mathrm{U}_{\text {unlabeled }}=\mathrm{U}_{\text {labeled }}\left(\mathrm{m}_{\text {unlabeled }} / \mathrm{m}_{\text {labeled }}\right)$

where $\mathrm{m}_{\text {labeled }}$ refers to the total mass $\left(\mathrm{g} \mathrm{m}^{-2}\right)$ of ${ }^{15} \mathrm{~N}$ labeled $\mathrm{N}$ injected per quadrat, and $\mathrm{m}_{\text {unlabeled }}$ refers to the mass of available $\mathrm{N}$ forms measured in soils. $\mathrm{U}_{\text {labeled }}\left(\mathrm{g} \mathrm{m}^{-2}\right)$ refers to uptake of ${ }^{15} \mathrm{~N}$ from the source $\mathrm{m}_{\text {labeled}}$, and $\mathrm{U}_{\text {unlabeled }}$ refers to uptake of available $\mathrm{N}$ from the source $m_{\text {unlabeled. }}$.

$\mathrm{U}_{\text {unlabeled divided by root biomass }}\left(\mathrm{g} \mathrm{m}^{-2}\right)$ and ${ }^{15} \mathrm{~N}$ labeling time (h) (Gioseffi et al. 2012), we would get $\mathrm{N}$ uptake rate by plants ( $\mu \mathrm{g} \mathrm{N} \mathrm{g}^{-1} \mathrm{~d}$.w. root $\mathrm{h}^{-1}$ ) (Recovery is not necessarily a direct function of uptake rate in the following section).
${ }^{15} \mathrm{~N}$ recovery in plants $\left(\mathrm{R}_{\text {plant }}, \%\right)$ was calculated by following equation (Clemmensen et al. 2008):

$\mathrm{R}_{\text {plant }}(\%)=\frac{\mathrm{U}_{\text {labeled }}}{15_{\text {Nadded }}} \times 100$

Where $U_{\text {labeled }}$ refers to the ${ }^{15} \mathrm{~N}$ mass uptake by plants, ${ }^{15} \mathrm{~N}_{\text {added }}$ refers to the total ${ }^{15} \mathrm{~N}$ mass added to the soil per square meter.

${ }^{15} \mathrm{~N}$ recovery in microbial biomass $\left(\mathrm{R}_{\mathrm{MB}}, \%\right)$ was calculated by the following equation (Zogg et al. 2000):

$\mathrm{R}_{\mathrm{MB}}(\%)=\left(\mathrm{R}_{\text {fum }}-\mathrm{R}_{\text {non-fum }}\right) / 15_{\mathrm{N}}$ added $\times 100$

Where $R_{\text {fum }}$ refers to the ${ }^{15} \mathrm{~N}$ mass recovered in fumigated soil extracts, $R_{\text {non-fum }}$ refers to the ${ }^{15} \mathrm{~N}$ mass recovered in non-fumigated soil extracts, ${ }^{15} \mathrm{~N}_{\text {added }}$ refers to the total ${ }^{15} \mathrm{~N}$ mass added to the soil per square meter.

Here we do not use any Ken in the calculation of $\mathrm{R}_{\mathrm{MB}}$. The added labeling ${ }^{15} \mathrm{~N}$ is in a state of disequilibrium in short-term ${ }^{15} \mathrm{~N}$ labeling experiment which could have underestimated microbial ${ }^{15} \mathrm{~N}$ uptake (Xu et al. 2011a).

The standard errors of the means are presented in the figures and tables as a variability parameter. A one-way ANOVA followed by Duncan tests was used to examine biomass and $\mathrm{N}$ uptake rate for the three dominant species. The significance of difference in ${ }^{15} \mathrm{~N}$ recovery between the microbes and the plants and ${ }^{15} \mathrm{~N}$ content among different plant species, different $\mathrm{N}$ forms and different labeling injection depths was examined using a multivariate ANOVA. The analysis was conducted with the SPSS 20.0 software package (SPSS Inc., Chicago, IL, USA). All the significant differences were tested at $P<0.05$.

\section{Results}

Biomass and root to shoot ratio

The aboveground biomasses were similar among the three dominant plant species (Fig. 1). However, there were significant differences in belowground biomass among C. squarrosa, A. frigida and A. capillaris (Fig. 1). The root to shoot ratio of $A$. frigida $(6.21 \pm 0.96)$ was significantly higher than the other two species, while C. squarrosa and A. capillaris were approximately the same. The root to shoot ratio of the three dominant species were greater than one (Fig. 1). 


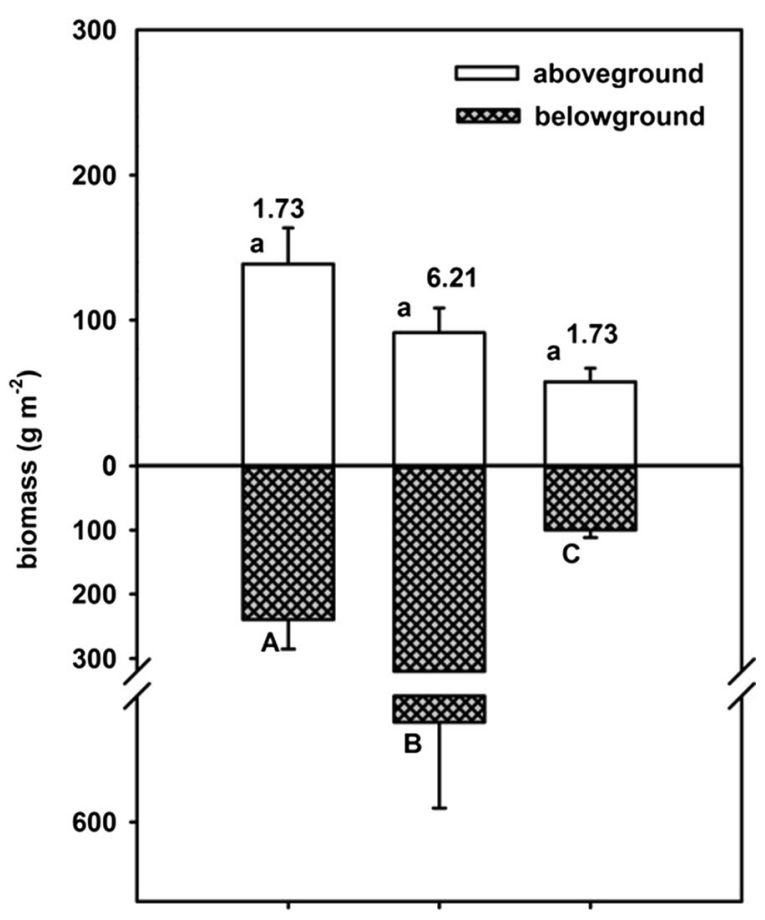

C. squarrosa $A$. frigida $A$. capillaris

Fig. 1 The biomass and root to shoot ratio (values) of the dominant plant species in the temperate grasslands of North China. The error bars show mean $\pm \operatorname{SE}(n=16)$. Different letters show significant differences among aboveground biomass and belowground biomass of the dominant plant species, and the values upon the bars were the root to shoot ratios

Diversity of the $\mathrm{N}$ uptake rate by plants

There were remarkable effects of species, chemical $\mathrm{N}$ forms and soil depth on the $\mathrm{N}$ uptake rate by plants (Fig. 2). The $\mathrm{N}$ uptake rates by $C$. squarrosa and A. capillaris were significantly higher than that of A. frigida $(P<0.001)$ in $\mathrm{NO}_{3}{ }^{-}$more than in $\mathrm{NH}_{4}{ }^{+}$and glycine $(P<0.001)$ and at depth of $0-5 \mathrm{~cm}$ more than at $5-15 \mathrm{~cm}$ depth $(P<0.001)$ (Fig. 2). This indicated that different dominant plant species could absorb different $\mathrm{N}$ forms at various soil depths.

There was an interactive effect of species $\times$ soil depth on the $\mathrm{N}$ uptake rate $(P<0.001)$. Generally, glycine $\mathrm{N}$ and $\mathrm{NO}_{3}{ }^{-}$uptake rates by the three dominant species decreased as the soil depth increased. This was especially true in that the decline of $A$. capillaris was faster than C. squarrosa and A. frigida. This indicated that there was spatial heterogeneity of $\mathrm{N}$ uptake by the dominant plants. Additionally, species $\times \mathrm{N}$ forms and $\mathrm{N}$ forms $\times$ soil depth have significantly interactive effects on the $\mathrm{N}$ uptake rate by plants $(P<0.001)$. Organic and inorganic nitrogen uptake rates by $C$. squarrosa and $A$. capillaris were significantly higher than by $A$. frigida, but $A$. frigida absorbed more $\mathrm{NO}_{3}{ }^{-}$(Fig. 2). At $0-5 \mathrm{~cm}$ depth, plants absorbed $\mathrm{NO}_{3}{ }^{-}$faster than glycine and $\mathrm{NH}_{4}{ }^{+}$, and the uptake rate of $\mathrm{NO}_{3}{ }^{-}$by plants decreased with increasing soil depth. There was no difference between $C$. squarrosa and A. capillaris uptake $\mathrm{NO}_{3}{ }^{-}$and $\mathrm{NH}_{4}{ }^{+}$ (Fig. 2). There was a significantly interactive effect of species $\times \mathrm{N}$ forms $\times$ soil depth (Table 2 ), which implied that $\mathrm{N}$ forms and soil depth greatly affect the $\mathrm{N}$ uptake by different plants.

Variation of inorganic $-{ }^{15} \mathrm{~N}$ recovered between the microbial biomass and the plants

There was a significant effect of species on $\mathrm{N}$ uptake by microbes in the steppe ecosystem. The patterns of ${ }^{15} \mathrm{~N}$ recovery by microbial biomass differed in the soil that the plants grew (Table 2, Fig. 3). The N uptake by microbes was significantly higher in the soil where A. frigida grew compared to the soil where C. squarrosa and A. capillaris grew (Fig. 3). There were also significantly interactive effects of species $\times \mathrm{N}$ forms and species $\times \mathrm{N}$ forms $\times$ soil depth on the microbes' $\mathrm{N}$ acquisition (Table 2, Fig. 3). ${ }^{15} \mathrm{NO}_{3}{ }^{-}$ uptake by microbes in the soil where $A$. frigid grew was higher than where $C$. squarrosa and A. capillaris were grown at both soil depths (Fig. 3a and b). ${ }^{15} \mathrm{NH}_{4}{ }^{+}$ uptake by microbes in the soil at $0-5 \mathrm{~cm}$ depth was much greater where A. frigida and A. capillaris grew than where $C$. squarrosa grew (Fig. 3c). At $5-15 \mathrm{~cm}$ depth, microbes in the soil where $A$. frigida grew absorbed more ${ }^{15} \mathrm{NH}_{4}{ }^{+}$than where $C$. squarrosa and A. capillaris grew (Fig. 3d).

There were significant effects of species, $\mathrm{N}$ forms and soil depth on ${ }^{15} \mathrm{~N}$ recovery by plants (Table 2, Fig. 3). Overall, ${ }^{15} \mathrm{~N}$ recovery was significantly higher in $A$. frigida and $A$. capillaris than in $C$. squarrosa, in ${ }^{15} \mathrm{NO}_{3}{ }^{-}$than in ${ }^{15} \mathrm{NH}_{4}{ }^{+}$and at $0-5 \mathrm{~cm}$ than at $5-15 \mathrm{~cm}$ soil depth. There were also significantly interactive effects of species $\times$ soil depth, species $\times \mathrm{N}$ forms, $\mathrm{N}$ forms $\times$ soil depth and species $\times \mathrm{N}$ forms $\times$ soil depth on ${ }^{15} \mathrm{~N}$ recovery by plants (Table 2 , Fig. 3 ). ${ }^{15} \mathrm{~N}$ recovery was higher with the addition of ${ }^{15} \mathrm{NO}_{3}{ }^{-}$than ${ }^{15} \mathrm{NH}_{4}{ }^{+}$at both $0-5 \mathrm{~cm}$ and $5-15 \mathrm{~cm}$ soil depths. ${ }^{15} \mathrm{~N}$ recovery of ${ }^{15} \mathrm{NO}_{3}{ }^{-}$by $A$. frigida or A. capillaris was higher than C. squarrosa. However, C. squarrosa and A. capillaris took up more ${ }^{15} \mathrm{NH}_{4}{ }^{+}$than $A$. frigida at $0-5 \mathrm{~cm}$ soil 


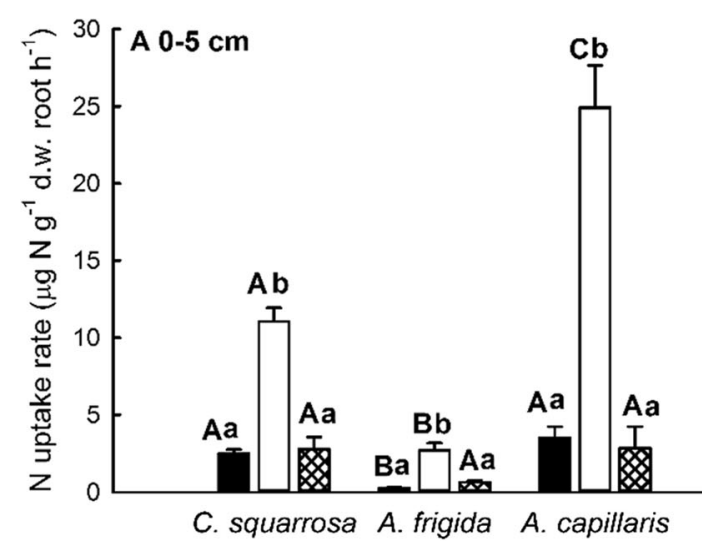

Fig. 2 The effects of species, $\mathrm{N}$ forms and soil depth on the $\mathrm{N}$ uptake rate by the dominant plant species in the temperate grasslands in northern China. The bars and error bars show means $\pm \operatorname{SE}(n=4)$. The uppercase and lowercase letters

depth. At 5-15 cm soil depth, C. squarrosa absorbed more ${ }^{15} \mathrm{NH}_{4}{ }^{+}$than $A$. capillaris and A. frigida.

Competition of $\mathrm{N}$ uptake between plants and microbes

The $\mathrm{N}$ competition between plants and microbes is obvious. ${ }^{15} \mathrm{~N}$ recovery by microbial biomass is significantly higher than by plants (Table 2, Fig. 3). There were significant effects and strong interactions of species, $\mathrm{N}$ forms and soil depth on $\mathrm{N}$ uptake by plants and microbes.

\section{Discussion}

Numerous studies have demonstrated that a variety of plant species can directly take up organic $\mathrm{N}$ from soil solution (Näsholm et al. 2009; Hill et al. 2011a;
B $5-15 \mathrm{~cm}$

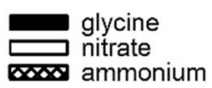

\$.8 ammonium

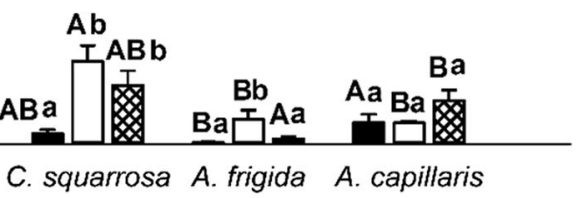

represent the difference between plant species and $\mathrm{N}$ forms, respectively. The bars sharing the same letter are not significantly different at $P=0.05$

Wilkinson et al. 2015). In this study, we confirmed that plant species in temperate grasslands also have the capacity to take up the added $\mathrm{N}$ in organic form, but its contribution to plant $\mathrm{N}$ nutrition is very lower than alpine plant species ( $\mathrm{Xu}$ et al. 2006, 2011a). Our results revealed that the dominant plant species in the temperate grassland absorbed a substantial amount of organic N (Fig. 1), agreed well with previous research in the temperate grasslands (Owen and Jones 2001; Weigelt et al. 2005) and alpine wetland (Gao et al. 2014). The percentage of glycine-N uptake by plants (6 to $25 \%$ ) in temperate grasslands of this study (Fig. 4) was in accordance with that on the Tibetan Plateau by plants in alpine meadow (2 to $24 \%)(\mathrm{Xu}$ et al. 2011a), less than in alpine wetland with $40 \%$ (Wang et al. 2012). The results suggest that organic $\mathrm{N}$ may be an additional
Table 2 ANOVA results for the effects of plant species, $\mathrm{N}$ forms, soil depth and their interactions on ${ }^{15} \mathrm{~N}$ recovery by microbes and plants

\begin{tabular}{|c|c|c|c|c|}
\hline \multirow[t]{2}{*}{ Sources of variation } & \multicolumn{2}{|c|}{${ }^{15} \mathrm{~N}$ recovery by microbes } & \multicolumn{2}{|c|}{${ }^{15} \mathrm{~N}$ recovery by plants } \\
\hline & $F$ value & $P$ values & $F$ values & $P$ values \\
\hline Species & 62.717 & $<0.001$ & 8.525 & $<0.001$ \\
\hline $\mathrm{N}$ forms & 5.279 & 0.028 & 92.972 & $<0.001$ \\
\hline Soil depth & 0.001 & 0.971 & 106.39 & $<0.001$ \\
\hline Species $\times$ Soil depth & 0.836 & 0.442 & 5.086 & $<0.011$ \\
\hline Species $\times \mathrm{N}$ forms & 8.955 & $<0.001$ & 17.038 & $<0.001$ \\
\hline $\mathrm{N}$ forms $\times$ Soil depth & 0.516 & 0.477 & 29.740 & $<0.001$ \\
\hline Species $\times N$ forms $\times$ Soil depth & 3.290 & 0.049 & 3.274 & 0.049 \\
\hline
\end{tabular}



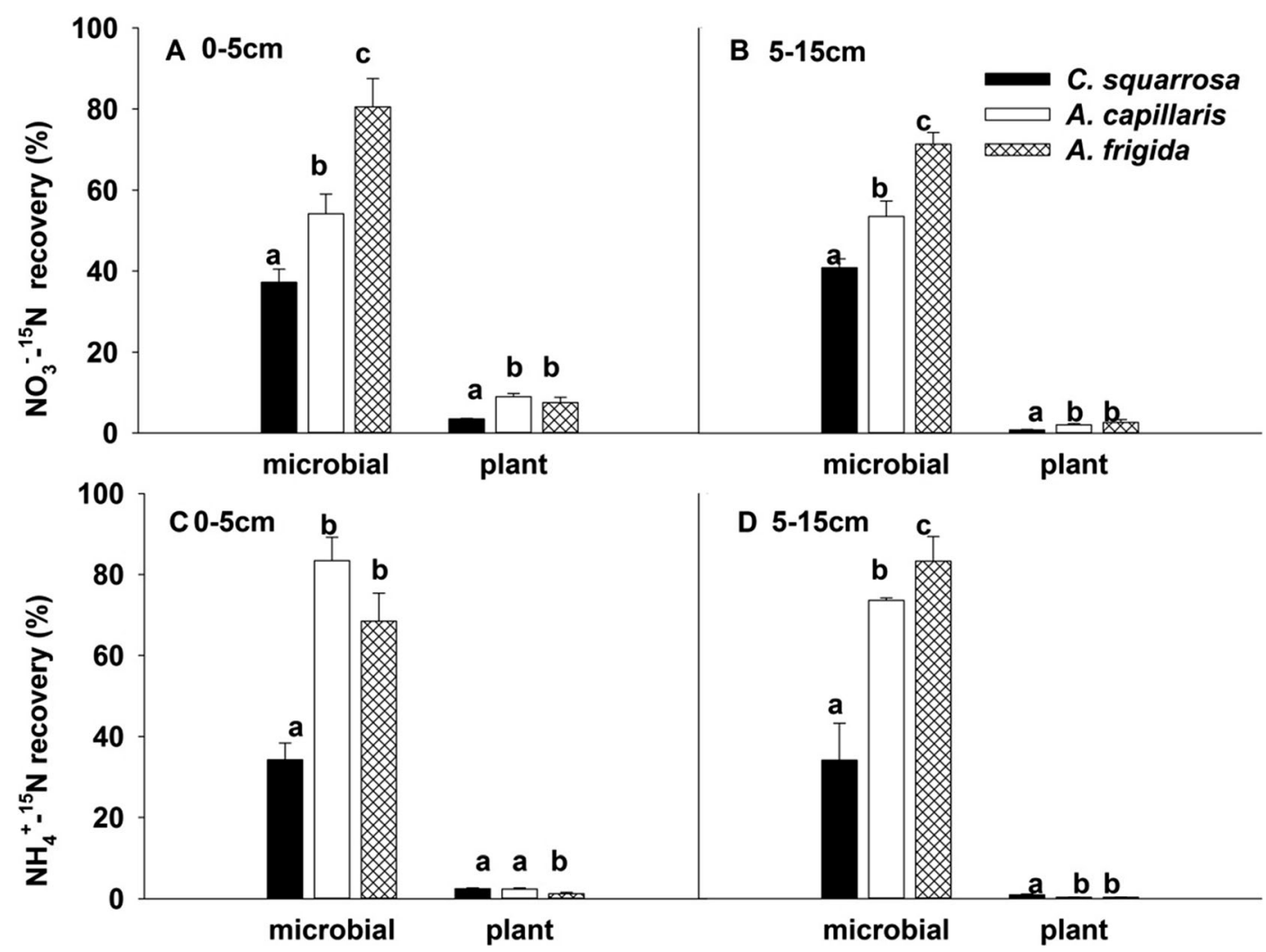

Fig. $3{ }^{15} \mathrm{~N}$ recovered by microbes and plants (\% of added ${ }^{15} \mathrm{~N}$ ) from ${ }^{15} \mathrm{NH}_{4}{ }^{+}$and ${ }^{15} \mathrm{NO}_{3}{ }^{-} 2 \mathrm{~h}$ after ${ }^{15} \mathrm{~N}$ injection at two soil depths in the temperate grasslands in northern China. The bars and error

important $\mathrm{N}$ source for the plant growth in temperate grasslands, and the plants would mainly utilize organic $\mathrm{N}$ to meet their basic nutrient demands in the soil of lower available inorganic $\mathrm{N}$.

The three dominant plants acquired more inorganic $\mathrm{N}$ and glycine-N from 0 to $5 \mathrm{~cm}$ soil depth than from 5 to $15 \mathrm{~cm}$ depth (Fig. 2), which showed different spatial patterns of $\mathrm{N}$ uptake among dominant plants. This might be related to the fact that most roots are typically located close to the soil surface (Table 3, Fig. 5) in all the ecosystems (Jackson et al. 1989; Kuzyakov and Xu 2013). The total $\mathrm{N}$ uptake rates (the sum of $\mathrm{N}$ uptake rates of three $\mathrm{N}$ forms) by A. capillaris and C. squarrosa were significantly higher than by $A$. frigida, although the total biomass and root to shoot ratio of $A$. frigida were the highest of all the plant species (Figs. 1 and 2). This result agrees well with previous findings that A. frigida is usually a dominant plant species that survives in the degraded grasslands (Zhan et al. 1999). Our results from the short time ${ }^{15} \mathrm{~N}$-labeling experiment revealed that in the long-term overgrazing grassland bars show means $\pm \mathrm{SE}(n=4)$. The bars sharing the same letter are not significantly different at $P=0.05$

ecosystems of North China, the most dominant plant A. frigida has its own unique $\mathrm{N}$ acquisition strategy. Based on the highest biomass and shoot to root ratio (Fig. 1), absorbing relatively less $\mathrm{N}$ (Fig. 3) in a short time and much more ${ }^{15} \mathrm{~N}$ recovered in soil microbes than in A. frigida (Fig. 4) for A. frigida, we inferred that $\mathrm{N}$ recovered in microbes would enter the soil and utilized by $A$. frigida as a most important $\mathrm{N}$ source and pool in the long run. A possible interpretation for this would be that a temporal niche for $\mathrm{N}$ acquisition occurs between plants and microbes. Initially, microbes often acquire more $\mathrm{N}$ than plants (Andresen et al. 2008) for soil microbes have larger surface to volume ratio. As time going, added $\mathrm{N}$ gradually released to soil and absorbed by plants because they show long life (Kuzyakov and $\mathrm{Xu}$ 2013). Mycorrhizal colonization status and host specificities of different plant species could probably regulate $\mathrm{N}$ acquisition by plants might be another reasonable explanation (Huang et al. 2009; Oses et al. 2008; Wu et al. 2013). In other words, this would further 
Fig. 4 The contribution of $\mathrm{NH}_{4}{ }^{+}$, $\mathrm{NO}_{3}{ }^{-}$and glycine to the total $\mathrm{N}$ uptake (as \%) of the dominant plant species at two soil depths $(n=4)$. The bars and error bars show means $\pm \operatorname{SE}(n=4)$

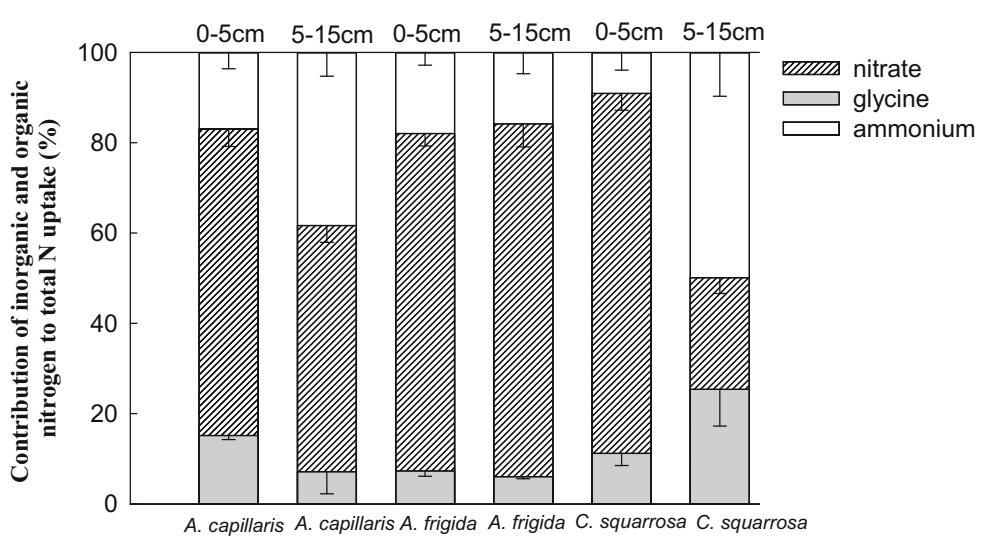

promote $A$. frigida to be more dominant in the N-limited grassland ecosystem.

Inorganic-N uptake by three dominant plants from $\mathrm{NH}_{4}{ }^{+}$and $\mathrm{NO}_{3}{ }^{-}$also showed a very different spatial pattern (Fig. 4). At $0-5 \mathrm{~cm}$ soil depth, $\mathrm{NO}_{3}{ }^{-}$uptake by plants was more than $\mathrm{NH}_{4}{ }^{+}$, perhaps because the diffusion rate of $\mathrm{NO}_{3}{ }^{-}$was faster than that of $\mathrm{NH}_{4}{ }^{+}$in topsoil $(0-5 \mathrm{~cm})$ (Nye and Tinker 1977; Owen and Jones 2001; Miller and Cramer 2005). At 5-15 cm soil depth, A. capillaris absorbed more $\mathrm{NO}_{3}{ }^{-}$than $C$. squarrosa but less $\mathrm{NH}_{4}{ }^{+}$than $C$. squarrosa. One possible explanation for this $\mathrm{N}$ uptake pattern is that certain plant species would be more like to absorb $\mathrm{NH}_{4}{ }^{+}$, and certain plant species might be more like to acquire more $\mathrm{NO}_{3}{ }^{-}$in the same soil conditions. This reflects that different plants differs in the nutrient element absorbing process, and the nature of dominant plant species in utilizing different $\mathrm{N}$ forms is the result of their long-term evolution and adaptation. Much more results indicated that plants absorbed more $\mathrm{NO}_{3}{ }^{-}$than $\mathrm{NH}_{4}{ }^{+}$(Song et al. 2007; Ashton et al. 2010), while still there were some researches proved plants tended to take up more $\mathrm{NH}_{4}{ }^{+}$ (Finzi and Berthrong 2005; Näsholm et al. 2009) with

Table 3 Root biomass of three dominant plant species at two rooting depths

\begin{tabular}{llll}
\hline $\begin{array}{l}\text { Rooting depth } \\
(\mathrm{cm})\end{array}$ & \multicolumn{2}{l}{ Root biomass $\left(\mathrm{g} \mathrm{m}^{-2}\right)$} & \\
\cline { 2 - 4 } & $\begin{array}{l}\text { Cleistogenes } \\
\text { squarrosa }\end{array}$ & $\begin{array}{l}\text { Artemisia } \\
\text { frigida }\end{array}$ & $\begin{array}{l}\text { Artemisia } \\
\text { capillaris }\end{array}$ \\
\hline $0-5$ & 146.0 & 331.1 & 80.1 \\
$5-15$ & 93.1 & 205.6 & 19.7 \\
$0-5 / 5-15$ ratio & $1.6 \pm 0.35$ & $1.6 \pm 0.17$ & $4.1 \pm 0.27$ \\
\hline
\end{tabular}

short time labeling $(<72 \mathrm{~h})$. The $\mathrm{N}$ uptake patterns of plants varied with seasons and soil depths (McKane et al. 2002; Xu et al. 2011a). And which could be affected by plant species, habitat conditions, mycorrhizal status, different physi-chemical and biological characteristics of N (Kaye and Hart 1997; Sorensen et al. 2008; Clemmensen et al. 2008; Näsholm et al. 2009; Wu et al. 2013).

In the N-limited grasslands of North China, the spatial variations of plant-microbial competition for absorbing inorganic $\mathrm{N}$ are important to gain a better understanding of plant-soil interactions in temperate grasslands (Fig. 2). $\mathrm{NO}_{3}{ }^{-}$and $\mathrm{NH}_{4}{ }^{+}$uptake by the three dominant plants declined with increasing soil depth (Fig. 2). In contrast, there was no clear trend for microbial uptake within the soil depths (Fig. 2). The result was in accordance with previous observations in alpine grasslands (Xu et al. 2011a) but was different than plant-microbial competition for inorganic $\mathrm{N}$ in topsoil $(0-5 \mathrm{~cm})$. Microbes are more competitive (Andresen et al. 2008) than plants at both soil depths even though the highest root density occurs in topsoil (Table 3, Fig. 5). A significantly greater amount of added inorganic-N was captured by the microbial biomass in the topsoil and subsoil. This result suggests that fast microbial turnover and the release of inorganic $\mathrm{N}$ into the plant-soil system is an important pathway for plant $\mathrm{N}$ capture in temperate grassland ecosystems. The microbial sequestration of added $\mathrm{N}$ might be an important mechanism of $\mathrm{N}$ retention in grasslands (Bardgett et al. 2003), and the result was similar with the research in the low-productivity systems in Lancashire, United Kingdom (Bardgett et al. 2003). Other research shows that soil microbes are more competitive for absorbing inorganic $\mathrm{N}$ in short-term labeling (Jackson et al. 1989; 


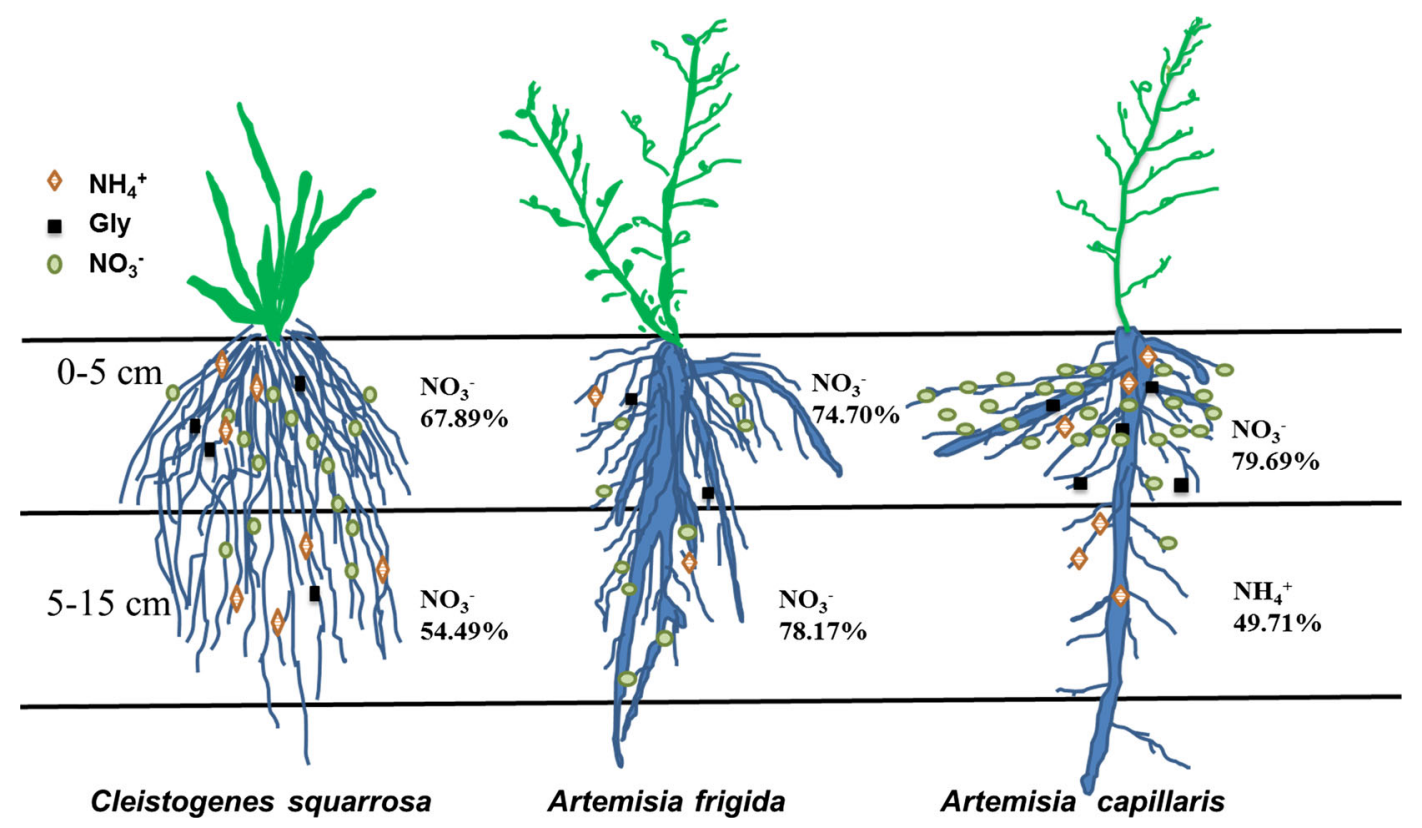

Fig. 5 The dominant $\mathrm{N}$ form of uptake by three different plant species in specific depths in temperate grasslands of North China

Hodge et al. 2000). This might be because microbes have faster growth rates and higher surface-to-volume ratios compared with the roots of plants (Rosswall 1982). Thus, even in soils with a higher density of roots (Table 3, Fig. 5), for example in the upper 0-5 cm depth in the grassland, most $\mathrm{N}$ would be taken up by microbes shortly after $\mathrm{N}$ addition. This reduces $\mathrm{N}$ leaching losses as a result of the limited uptake capacity of roots. The various $\mathrm{N}$ acquisition strategies are a benefit for ecosystem development and species evolution. The rapid allocation of inorganic $\mathrm{N}$ in microbes (Jones and Kielland 2002; Bardgett et al. 2003; Fischer et al. 2010) is ascribed to their inherent uptake capacity. This is an important adaptation of the ecosystem against possible $\mathrm{N}$ loss by leaching (Bardgett et al. 2003; Kuzyakov and Xu 2013). Additionally, this fast preliminary microbial immobilization of mineral $\mathrm{N}$ and amino acids probably affected the plant species competition. In particular, enhanced rhizodeposition provides a strong selection pressure for those microbes retained close to the root surfaces and further promote the development of symbiotic and mutually beneficial effects. There were some results revealed soil microbes effectively out-competed plants for added $\mathrm{N}$ within $50 \mathrm{~h}$ after ${ }^{15} \mathrm{~N}$ addition, however, in the longer term, plant out-competed microbes for added $\mathrm{N}$ after 33 days due to microbial turnover releasing $\mathrm{N}$ back to the plant-soil system and subsequent plant uptake in temperate grasslands
(Zogg et al. 2000; Hodge et al. 2000; Harrison et al. 2007). This might be the reason of the temporal dynamic of nutrient partitioning between microbes and plants (Xu et al. 2011b; Kuzyakov and Xu 2013; Gao et al. 2014).

Plant-microbial competition for $\mathrm{N}$ strongly depends on spatio-temporal variations and root density (Xu et al. 2011b). Most previous studies showed that microbes out-competed plants within minutes to hours due to a large surface-to-volume ratio of microbes and rapid growth rates compared with plant roots (Owen and Jones 2001; Wilkinson et al. 2014). With timing, plants gradually acquire more $\mathrm{N}$ due to their long life and are super competitor in a long run (Kuzyakov and $\mathrm{Xu}$ 2013). Over soil depth, plants showed strong competition ability in the surface soil while microbes perform better in subsoil (Xu et al. 2011b). Additionally, the distribution of roots and soil microbes and the mobility of the different $\mathrm{N}$ forms are important factors controlling competition for inorganic $\mathrm{N}$ between plants and microbes (Jackson et al. 1989). All three dominant plants absorbed more ${ }^{15} \mathrm{NO}_{3}{ }^{-}$than ${ }^{15} \mathrm{NH}_{4}{ }^{+}$(Fig. 3), which is consistent with previous studies in tundra and alpine meadows (Miller et al. 2007; Song et al. 2007; Xu et al. 2011a). Our results demonstrated that microbes had a higher recovery of $\mathrm{NO}_{3}{ }^{-}$, and one reasonable explanation was that the higher rate of microbial $\mathrm{NO}_{3}{ }^{-}$ uptake might be the result of the occurrence of microsites where $\mathrm{NH}_{4}{ }^{+}$is depleted (Jackson et al. 1989). 
We conclude that the dominant plant species in the degraded grassland ecosystem of North China have different uptake patterns of organic and inorganic $\mathrm{N}$ at two soil depths, and $\mathrm{N}$ uptake by plants was more at $0-5$ $\mathrm{cm}$ than at $5-15 \mathrm{~cm}$. Competition for $\mathrm{NH}_{4}{ }^{+}$and $\mathrm{NO}_{3}{ }^{-}$ between plants and microbes demonstrates that microbes have advantages over plants for inorganic absorption in these short-term ${ }^{15} \mathrm{~N}$ experiments. There are spatial patterns of inorganic and organic plant uptake and the competition between plants and microbes. Based on the results, we can partly explain why these dominant plant species can coexist in degraded grasslands due to overgrazing.

For this study, we did not determine the glycine- ${ }^{15} \mathrm{~N}$ concentration and the competition for organic $\mathrm{N}$ (glycine) between plants and microbes. In light of this study, this is a most important issue for us to be concentrated on the organic $\mathrm{N}$ acquisition between plants and microbes in the future.

Acknowledgments This research was supported by the "National Key Basic Research Program of China" (Grant No. 2014CB138803), the Fundamental Research Funds for Central Universities (Grant No. 2014KJJCB01) and the State Key Laboratory of Earth Surface Processes and Resource Ecology, Beijing Normal University (Grant No. 2009-RC-03) as well as National Natural Science Foundation of China (31470560, 41071209 and 31570468).

\section{References}

Andresen LC, Jonasson S, Ström L, Michelsen A (2008) Uptake of pulse injected nitrogen by soil microbes and mycorrhizal and non-mycorrhizal plants in a species-diverse subarctic heath ecosystem. Plant Soil 313(1-2):283-295

Ashton IW, Miller AE, Bowman WD, Suding KN (2010) Niche complementarity due to plasticity in resource use: plant partitioning of chemical $\mathrm{N}$ forms. Ecology 91(11):32523260

Bardgett RD, Streeter TC, Cole L, Hartley IR (2002) Linkages between soil biota, nitrogen availability, and plant nitrogen uptake in a mountain ecosystem in the Scottish highlands. Appl Soil Ecol 19:121-134

Bardgett RD, Streeter TC, Bol R (2003) Soil microbes compete effectively with plants for organic-nitrogen inputs to temperate grasslands. Ecology 84:1277-1287

Brookes PC, Landman A, Pruden G, Jenkinson DS (1985) Chloroform fumigation and the release of soil nitrogen: a rapid direct extraction method to measure microbial biomass nitrogen in soil. Soil Biol Biochem 17:837-842

Buckeridge KM, Jefferies RL (2007) Vegetation loss alters soil nitrogen dynamics in an Arctic salt marsh. J Ecol 95:283-293
Chinese Academy of Science (2001) The Chinese soil taxonomic classification retrieval, 3rd edn. Press of University of Science and Technology of China, Hefei

Clemmensen KE, Sorensen PL, Michelsen A, Jonasson S, Ström L (2008) Site-dependent $\mathrm{N}$ uptake from $\mathrm{N}$-form mixtures by arctic plants, soil microbes and ectomycorrhizal fungi. Oecologia 155(4):771-783

Finzi AC, Berthrong ST (2005) The uptake of amino acids by microbes and trees in three cold-temperate forests. Ecology 86(12):3345-3353

Fischer H, Ingwersen J, Kuzyakov Y (2010) Microbial uptake of low-molecular-weight organic substances out-competes sorption in soil. Eur J Soil Sci 61:504-513

Gao JQ, Mo Y, Xu XL, Zhang XW, Yu FH (2014) Spatiotemporal variations affect uptake of inorganic and organic nitrogen by dominant plant species in an alpine wetland. Plant Soil 381: 271-278

Gioseffi E, de Neergaard A, Schjoerring JK (2012) Interactions between uptake of amino acids and inorganic nitrogen in wheat plants. Biogeosciences 9(4):1509-1518

Harrison KA, Roland B, Bardgett RD (2007) Preferences for different nitrogen forms by coexisting plant species and soil microbes. Ecology 88:989-999

Harrison KA, Bol R, Bardgett RD (2008) Do plant species with different growth strategies vary in their ability to compete with soil microbes for chemical forms of nitrogen? Soil Biol Biochem 40:228-237

Hertenberger G, Wanek W (2004) Evaluation of methods to measure differential $15 \mathrm{~N}$ labeling of soil and root $\mathrm{N}$ pools for studies of root exudation. Rapid Commun Mass Spectrom 18(20):2415-2425

Hill PW, Farrar J, Roberts P, Farrell M, Grant H, Newsham KK, Hopkins DW, Bardgett RD, Jones DL (2011a) Vascular plant success in a warming Antarctic may be due to efficient nitrogen acquisition. Nat Clim Chang 1(1):50-53

Hill PW, Quilliam RS, DeLuca TH, Farrar J, Farrell M, Roberts P, Newsham KK, Hopkins DW, Bardgett RD, Jones DL (2011b) Acquisition and assimilation of nitrogen as peptidebound and denantiomers of amino acids by wheat. PLoS One 6(4):e19220

Hill PW, Farrell M, Jones DL (2012) Bigger may be better in soil $\mathrm{N}$ cycling: does rapid acquisition of small 1-peptides by soil microbes dominate fluxes of protein-derived $\mathrm{N}$ in soil? Soil Biol Biochem 48:106-112

Hodge A, Stewart J, Robinson D, Griffiths BS, Fitter AH (2000) Competition between roots and soil micro-organisms for nutrients from nitrogen-rich patches of varying complexity. J Ecol 88:150-164

Huang WY, Cai YZ, Surveswaran S, Hyde KD, Corke H, Sun M (2009) Molecular phylogenetic identification of endophytic fungi isolated from three Artemisia species. Fungal Divers 36:69-88

Jackson LE, Schimel JP, Firestone MK (1989) Short-term partitioning of ammonium and nitrate between plants and microbes in an annual grassland. Soil Biol Biochem 21:409-415

Jaeger CH, Monson RK, Fisk MC, Schmidt SK (1999) Seasonal partitioning of nitrogen by plants and soil microorganisms in an alpine ecosystem. Ecology 80:1883-1891

Jones DL, Kielland K (2002) Soil amino acid turnover dominates the nitrogen flux in permafrost-dominated taiga forest soils. Soil Biol Biochem 34:209-219 
Kalembasa SJ, Jenkinson DS (1973) A comparative study of titrimetric and gravimetric methods for the determination of organic carbon in soil. J Sci Food Agric 24:1085-1090

Kaštovská E, Šantrůčková H (2011) Comparison of uptake of different $\mathrm{N}$ forms by soil microorganisms and two wetgrassland plants: a pot study. Soil Biol Biochem 43: 1285-1291

Kaye JP, Hart SC (1997) Competition for nitrogen between plants and soil microorganisms. Trends Ecol Evol 12(4):139-143

Kleinebecker T, Hölzel N, Prati D, Schmitt B, Fischer M, Klaus VH (2014) Evidence from the real world: ${ }^{15} \mathrm{~N}$ natural abundances reveal enhanced nitrogen use at high plant diversity in central European grasslands. J Ecol 102:456-465

Kuzyakov Y, Xu XL (2013) Competition between roots and microorganisms for nitrogen: mechanisms and ecological relevance. New Phytol 198:656-669

Lambers H, Mougel C, Jaillard B, Hinsinger P (2009) Plantmicrobe-soil interactions in the rhizosphere: an evolutionary perspective. Plant Soil 321:83-115

Lebauer DS, Treseder KK (2008) Nitrogen limitation of net primary productivity in terrestrial ecosystem is globally distributed. Ecology 89:371-379

Marion GM, Miller PC, Kummerow J, Oechel WC (1982) Competition for nitrogen in a tussock tundra ecosystem. Plant Soil 66:317-327

McKane RB, Johnson LC, Shaver GR, Nadelhoffer KJ, Rastetter EB, Fry B, Giblin AE, Kielland K, Kwiatkowski BL, Laundre JL, Murray G (2002) Resource-based niches provide a basis for plant species diversity and dominance in arctic tundra. Nature 415:68-71

Miller AE, Bowman WD (2003) Alpine plants show species-level differences in the uptake of organic and inorganic nitrogen. Plant Soil 250:283-292

Miller AJ, Cramer MD (2005) Root physiology from gene to function. In: Lambers H, Colmer TD (eds) Root nitrogen acquisition and assimilation, vol 4. Springer, Netherlands, pp. $1-36$

Miller AE, Bowman WD, Suding KN (2007) Plant uptake of inorganic and organic nitrogen: neighbor identity matters. Ecology 88(7):1832-1840

Näsholm T, Sandberg G, Ericsson A (1987) Quantitative analysis of amino acids in conifer tissues by high-performance liquid chromatography and fluorescence detection of their 9fluorenylmethyl chloroformate derivatives. J Chromatogr A 396:225-236

Näsholm T, Kielland K, Ganeteg U (2009) Uptake of organic nitrogen by plants. New Phytol 182:31-48

Nye PH, Tinker PB (1977) Solute movement in the soil-root systems. University of California Press, Berkeley

Oses R, Valenzuela S, Freer J, Sanfuentes E, Rodríguez J (2008) Fungal endophytes in xylem of healthy Chilean trees and their possible role in early wood decay. Fungal Divers 33:77-86

Owen AG, Jones DL (2001) Competition for amino acids between wheat roots and rhizosphere microorganisms and the role of amino acids in plant $\mathrm{N}$ acquisition. Soil Biol Biochem 33: 651-657

Paungfoo-Lonhienne C, Lonhienne TG, Rentsch D, Robinson N, Christie M, Webb RI, Gamage HK, Carroll BJ, Schenk PM, Schmidt S (2008) Plants can use protein as a nitrogen source without assistance from other organisms. Proc Natl Acad Sci U S A 105(11):4524-4529

Paungfoo-Lonhienne C, Visser J, Lonhienne TGA, Schmidt S (2012) Past, present and future of organic nutrients. Plant Soil 359(1-2):1-18

Pruden G, Powlson DS, Jenkinson DS (1985) The measurement of ${ }^{15} \mathrm{~N}$ in soil and plant material. Fert Res 6(3):205-218

Raab TK, Lipson DA, Monson RK (1996) Non-mycorrhizal uptake of amino acids by roots of the alpine sedge Kobresia myosuroides: implications for the alpine nitrogen cycle. Oecologia 108:488-494

Raab TK, Lipson DA, Monson RK (1999) Soil amino acid utilization among species of the cyperaceae: plant and soil processes. Ecology 80:2408-2419

Rosswall T (1982) Microbiological regulation of the biogeochemical nitrogen cycle. Plant Soil 67:15-34

Schimel JP, Bennett J (2004) Nitrogen mineralization: challenges of a changing paradigm. Ecology 85:591-602

Schimel JP, Chapin FS (1996) Tundra plant uptake of amino acid and $\mathrm{NH}_{4}{ }^{+}$nitrogen in situ: plants complete well for amino acid N. Ecology 77:2142-2147

Soil Survey Staff (1987) Keys to soil taxonomy, 3rd edn. Cornell University, New York

Song MH, Xu XL, Hu QW, Tian YQ, Ouyang H, Zhou CP (2007) Interactions of plant species mediated plant competition for inorganic nitrogen with soil microorganisms in an alpine meadow. Plant Soil 297:127-137

Sorensen PL, Michelsen A, Jonasson S (2008) Ecosystem partitioning of ${ }^{15} \mathrm{~N}$-glycine after long-term climate and nutrient manipulations, plant clipping and addition of labile carbon in a subarctic heath tundra. Soil Biol Biochem 40:2344-2350

Vitousek P, Howarth R (1991) Nitrogen limitation on land and in the sea: how can it occur? Biogeochemistry 13:87-115

Wang WY, Ma YG, Xu J, Wang HC, Zhu JF, Zhou HK (2012) The uptake diversity of soil nitrogen nutrients by main plant species in Kobresia humilis alpine meadow on the QinghaiTibet plateau. Sci China Earth Sci 55:1688-1695

Weigelt A, Bol R, Bardgett RD (2005) Preferential uptake of soil nitrogen forms by grassland plant species. Oecologia 142 : $627-635$

Werth M, Kuzyakov Y (2010) ${ }^{13} \mathrm{C}$ fractionation at the rootmicroorganisms-soil interface: a review and outlook for partitioning studies. Soil Biol Biochem 42(9):1372-1384

Wilkinson A, Hill PW, Farrar JF, Jones DL, Bardgett RD (2014) Rapid microbial uptake and mineralization of amino acids and peptides along a grassland productivity gradient. Soil Biol Biochem 72:75-83

Wilkinson A, Hill PW, Vaieretti MV, Farrar JF, Jones DL, Bardgett RD (2015) Challenging the paradigm of nitrogen cycling: no evidence of in situ resource partitioning by coexisting plant species in grasslands of contrasting fertility. Ecol Evol 5(2): 275-287

Wu HH, Dannenmann M, Fanselow N, Wolf B, Yao ZS, Wu X, Brüggemann N, Zheng XH, Han XG, Dittert K, ButterbachBahl K (2011) Feedback of grazing on gross rates of $N$ mineralization and inorganic $\mathrm{N}$ partitioning in steppe soils of inner Mongolia. Plant Soil 340:127-139

Wu JR, Ma HC, Xu XL, Qiao N (2013) Mycorrhizas alter nitrogen acquisition pattern of a soil dwelling orchid (Cymbidium 
goeringii): evidence from a short-term ${ }^{15} \mathrm{~N}$ experiment. Ann Bot 111:1181-1187

Xu L, Gao Q, Wang YL (2014) Species richness within a six-year slope exclosure in a temperate grassland and its relationship with aboveground biomass. Ecol Environ Sci 23(3): 398-405

Xu XL, Ouyang H, Kuzyakov Y, Richter A, Wanek W (2006) Significance of organic nitrogen acquisition for dominant plant species in an alpine meadow on the Tibet plateau, China. Plant Soil 285(1-2):221-231

Xu XL, Ouyang H, Cao GM, Richter A, Wanek W, Kuzyakov Y (2011a) Dominant plant species shift their nitrogen uptake patterns in response to nutrient enrichment caused by a fungal fairy in an alpine meadow. Plant Soil 341:495-504

Xu XL, Ouyang H, Richter A, Wanek W, Cao GM, Kuzyakov Y (2011b) Spatio-temporal variations determine plant-microbe competition for inorganic nitrogen in an alpine meadow. $\mathrm{J}$ Ecol 99:563-571

Zhan BL, Chen SH, Zhang H, Cao LX, Buren JY (1999) A research of characteristics and ecological distribution of Artemisia frigida. J Inn Mongolia Inst Agric Anim Husb 20:1-7

Zhang YH, He NP, Zhang GM, Huang JH, Wang QB, Pan QM, Han XG (2013) Ammonia emissions from soil under sheep grazing in inner Mongolian grasslands of China. J Arid Land 5:155-165

Zhu WX, Carreiro MM (2004) Temporal and spatial variations in nitrogen transformations in deciduous forest ecosystems along an urban rural gradient. Soil Biol Biochem 36:267-278

Zogg GP, Zak DR, Pregitzer KS, Burton AJ (2000) Microbial immobilization and the retention of anthropogenic nitrate in a northern hardwood forest. Ecology 81:1858-1866 